\title{
Influence of treatment including second molars on final and postretention molar angulation
}

\author{
Luiz Filiphe Gonçalves Canutoํ․, Karina Maria Salvatores de Freitas², Marcos Roberto de Freitas ${ }^{3}$, Rodrigo Hermont Cançado ${ }^{4}$
}

Objective: Evaluate axial mesiodistal inclinations of the mandibular molars in orthodontically treated cases, analyzing whether inclusion of second mandibular molars in treatment mechanics has any influence on final and postretention molars angulations. Methods: The sample comprised 150 panoramic radiographs of 50 patients. Patients were treated with extraction of four first premolars and divided into 2 groups: Group 1 comprised 25 subjects without inclusion of mandibular second molars during orthodontic treatment, whereas Group 2 comprised 25 subjects with inclusion of mandibular second molars. Panoramic radiographs at three observation times were evaluated: pretreatment, posttreatment and postretention. The statistical analysis included one-way analysis of variance (ANOVA) for intragroup evaluation and independent t-tests for intergroup comparisons. Results: Intragroup analysis demonstrated significant uprighting of mandibular first and second molars during treatment in Group 2, which remained stable during the postretention stage. Intergroup comparison demonstrated that Group 2 presented first and second molars significantly more uprighted in relation to Group 1 in both post-treatment and postretention stages. Conclusions: It was concluded that inclusion of mandibular second molars in the orthodontic mechanics is relevant not only to correct the angulation of these teeth, but also to aid mandibular first molars uprighting.

Keywords: Panoramic X-ray. Tooth angulation. Tooth movement.

Objetivo: analisar a influência da inclusão dos segundos molares inferiores durante a mecânica ortodôntica nas angulações dos molares ao final do tratamento e na fase de pós-contenção. Métodos: a amostra consistiu em 150 radiografias panorâmicas de 50 pacientes avaliados antes, após o tratamento e no período de pós-contenção. Os pacientes foram tratados com extrações dos quatro primeiros pré-molares, e divididos em dois grupos: grupo 1, composto por 25 pacientes com segundo molares incluídos na mecânica ortodôntica; grupo 2, 25 pacientes cujos segundos molares não foram incluídos na mecânica ortodôntica. As angulações dos primeiros e segundos molares inferiores foram comparadas nas fases estudadas utilizando-se a Análise de Variância (análise intragrupo) e o teste $t$ independente (análise intergrupos). Resultados: a análise intragrupo, realizada no grupo 2, demonstrou que ocorreu uma verticalização significativa dos primeiros e segundos molares inferiores durante o tratamento, que se manteve estável na fase de pós-contenção. Os resultados da análise intergrupos demonstraram diferenças significativas na angulação dos primeiros e segundos molares após o tratamento e na fase de pós-contenção. Conclusão: a inclusão dos segundos molares inferiores à mecânica ortodôntica apresenta-se relevante, não apenas para corrigir a angulação desses dentes, mas, também, para auxiliar a correção da angulação dos primeiros molares permanentes.

Palavras-chave: Radiografia panorâmica. Ortodontia corretiva. Oclusão dentária.

${ }^{1}$ Professor of graduate program in Orthodontics at the Brazilian Dental Association / Pernambuco (ABO-PE).

${ }^{2}$ Professor of the graduate program in Orthodontics at UNINGÁ.

${ }^{3}$ Full professor of Pediatric Dentistry, Orthodontics and Public Health at USP, Bauru Dental School.

${ }^{4}$ Associate professor at UNINGÁ.
How to cite this article: Canuto LFG, Freitas KMS, Freitas MR, Cançado RH. Influence of treatment including second molars on final and postretention molar angulation. Dental Press J Orthod. 2013 Sept-Oct;18(5):121-7.

Submitted: September 20, 2011 - Revised and accepted: December 27, 2011

" The authors report no commercial, proprietary or financial interest in the products or companies described in this article.

Contact address: Luiz Filiphe Gonçalves Canuto

Rua José Bonifácio, 205 - S1 109 - Madalena - Recife/PE, Brazil

CEP: 50.710-000-E-mail: luizfiliphecanuto@yahoo.com.br 


\section{INTRODUCTION}

The importance of appropriate mesiodistal teeth angulation in orthodontic patients has been emphasized by many clinicians. In 1972, Andrews reported that tooth angulation is one of the 6 keys to be evaluated in ideal static occlusions. ${ }^{1}$

It has been reported that the final spatial orientation of each tooth should be such that it can best withstand the forces during function. Corrected angulation is universally accepted, and other several related parameters have been studied. These include periodontal health, ${ }^{1,2,3}$ even distribution of occlusal forces through contact points, tight posterior occlusion, no spaces as well as retention and stability of orthodontically closed extraction sites. ${ }^{1,4-7}$ The American Board of Orthodontics has included assessment of mesiodistal angulation in panoramic radiographs as a parameter for evaluating finished cases for orthodontists aspiring to be board diplomate.

Adequate mesiodistal teeth angulations with roots parallel to each other are frequently mentioned in the literature $\mathrm{e}^{1,3,8,9-13}$ as a fact that not only improves teeth alignment stability in their apical bases, but also allows normal maxilomandibular occlusion. ${ }^{6}$ Moreover, an adequate mesiodistal positioning allows a uniform distribution of occlusal forces through contact points and contributes to overall treatment stability. $3,6,10$

Given the importance of appropriate mesiodistal teeth angulation in orthodontic patients regarding quality and stability of treatment, the authors aimed to investigate the influence of mandibular second molars inclusion in orthodontic mechanics on final and postretention molar angulations.

\section{MATERIAL AND METHODS}

\section{Material}

The sample comprised 150 panoramic radiographs of 50 young patients of both genders. The radiographs were taken from the files of Pediatric Dentistry, Orthodontics and Public Health Department at University of São Paulo (USP), Bauru Dental School. Each case was evaluated at three stages: pretreatment $\left(T_{1}\right)$, posttreatment $\left(T_{2}\right)$ and after a minimum of 3 years of follow-up $\left(\mathrm{T}_{3}\right)$.

When selecting the sample, the following inclusion criteria were applied: cases initially presenting Class I or Class II malocclusion, treated with fixed Edgewise ap- pliances and extraction of four first premolars. All subjects had all permanent teeth erupted except the third molars at the pretreatment stage. Other inclusion criteria were patients with no history of previous interceptive orthodontic treatment, absence of root dilaceration or mandibular skeletal asymmetries.

After active treatment, all patients wore a modified Hawley retainer in the maxillary arch, full time for the first 12 months and during sleep for the next 6 months. A lingual canine-to-canine mandibular bonded retainer was placed and left for a mean period of 3 years.

\section{Methods}

The sample was divided into two groups:

» Group 1: 25 patients (14 female; 11 male) in whom the mandibular second molars were not included in treatment mechanics.

» Group 2: 25 patients (15 female; 10 male) with mandibular second molars included in treatment mechanics.

The mean pretreatment age was $13.29 \pm 1.44$ years for Group 1 and $12.95 \pm 1.26$ years for Group 2 . The mean treatment, retention and postretention evaluation times of each group are shown in Table 1.

First and second molar angulations were evaluated with panoramic radiographs (orthopantomography) traced manually by a single investigator, in acetate paper (Ultraphan Paper $^{\circledR}$, Berlin, Germany).

Table 1 - Descriptive statistics of treatment, retention and postretention evaluation mean times for Groups 1 and 2, with and without inclusion of second molars, respectively.

\begin{tabular}{|c|c|c|}
\hline Time (years) & $\begin{array}{l}\text { Group } 1 \\
2^{\text {nd }} \text { molar not included } \\
\qquad(n=25)\end{array}$ & $\begin{array}{l}\text { Group } 2 \\
2^{\text {nd }} \text { molar included } \\
\qquad(n=25)\end{array}$ \\
\hline & Mean \pm SD & Mean \pm SD \\
\hline Treatment & $2.41 \pm 0.64$ & $2.45 \pm 0.53$ \\
\hline Retention & $1.33 \pm 0.51$ & $1.49 \pm 0.76$ \\
\hline Posttreatment & $4.84 \pm 2.38$ & $4.18 \pm 2.47$ \\
\hline
\end{tabular}




\section{Tracing method}

The tracing procedure of the initial, posttreatment and postretention radiographs was conducted in four phases: a) Delineation of dentoskeletal structures; b) Definition of reference points; c) Definition of horizontal and vertical reference lines; d) Measurement of tooth angulation (Fig 1).

\section{a) Delineation of dentoskeletal structures:}

The external outline of the mandible, mental foramen, and outlines of mandibular first and second molars roots and crowns were traced.

\section{b) Definition of landmarks:}

The definition of the landmarks was performed as proposed by Tavano et al: ${ }^{14}$

1) Right mental foramen (RMF) - The central point of the right mental foramen.

2) Left mental foramen (LMF) - The central point of the left mental foramen.

\section{c) Tracing of horizontal and vertical reference lines:}

1) Intermental line (IL): Line passing through the centers of the right and left mental foramens.

2) First and second molars long axes: The long axes of the mentioned teeth were determined as the mean of the images of mesial and distal root canals ${ }^{13}$.

\section{d) Angles measurement:}

The angles formed by the Intermental line (IL) and the long axes of the first and second mandibular molars were then measured (Fig 1).

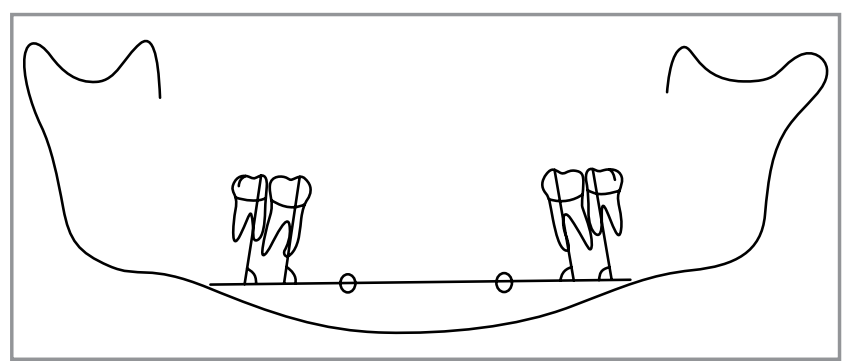

Figure 1 - Manual tracing performed at initial, final and posttreatment panoramic radiographs involving the delineation of dentoskeletal structures, demarcation of landmarks (RMF and LMF), vertical and horizontal reference lines and measurement of dental angulations.

\section{Statistical analyses}

Statistical analysis was performed with Statistica software (Statistica for Windows, version 7.0, StatSoft Inc).

To avoid type I error (probability of accepting the alternative hypothesis $\mathrm{H} 1$ and be wrong) sample was calculated considering $\alpha=5 \%$ (type I error), $\beta=20 \%$ (type II error), an estimated variability (s) of 5 degrees and a minimum detectable difference (d) of 5 degrees.

In each group, means and standard deviations for the mesiodistal inclination of the four evaluated teeth (left mandibular first molar-36; left mandibular second molar-37; right mandibular first molar-46; and right mandibular second molar-47) were determined. The intragroup comparison of these variables at the three observation stages was performed by one-way dependent ANOVA and Tukey tests as a second step. For intergroup comparison, t-tests were used. Prior to the use of ANOVA and t-tests, analyses of data normality and homoscedasticity of the groups was performed with Kolmogorov-Smirnov and Levene tests, respectively.

\section{Method error}

Within a week interval from the first measurement, 30 randomly selected radiographs were retraced and remeasured by the same examiner. The random error was calculated according to Dahlberg's formula $\left(\mathrm{Se}^{2}=\Sigma \mathrm{d}^{2} / 2 \mathrm{n}\right)$ and the systematic error was calculated with dependent t-tests, for $\mathrm{p}<0.05$.

\section{RESULTS}

Results for power analysis showed that a sample with 23 patients in each group would give a $80 \%$ ability to detect differences, whereas a sample comprising 26 patients in each group would give 85\%.

Results for the data distribution evaluation performed by the Kolmogorov-Smirnov test showed $p>0.05$ for both groups, for all variables evaluated, indicating that the data had normal distribution. Levene test was used to verify homoscedasticity. All results exhibited $p>0.05$ for both groups, during the three stages evaluated. Thus, it was concluded that there was homogeneity of variables and that the ANOVA test could be applied for intragroup analysis.

The results for intragroup comparison in Group 1 (\#37 and \#47 teeth not included) demonstrated no statistically significant differences between the mean values for the mesiodistal inclinations of the teeth $(36,37,46$ and 47$)$ at 
the three evaluated stages. On the other hand, results for the intragroup comparison in Group 2 (\#37 and \#47 teeth included) demonstrated significant uprighting of mandibular first and second molars throughout treatment, which remained stable during the postretention stage (Table 2).

Intergroup comparison demonstrated that Group 2 presented the first and second molars significantly uprighted in relation to Group 1 at both posttreatment and postretention stages (Table 3).

No significant systematic errors were detected and the major random error was of 1.27 degrees for the left mandibular first molar mesiodistal inclination.

\section{DISCUSSION}

Throughout this research, significant efforts were expended in order to minimize, or at least control the errors deriving from the procedures involved in panoramic radiograph tracings, demarcation of landmarks and measurement of the variables investigated. Knowledge of the methodology precision provided more reliable results. It was observed that the results obtained for random and systematic errors were within acceptable parameters, thus, not influencing the results and conclusions of the present study.

The methodology of this study was based on previous researches ${ }^{9,13,14}$ that also used panoramic radiographs to obtain tooth angulation measurements. Panoramic radiographs are ordinarily used in orthodontic practice to provide significant information about teeth, axial inclinations, maturation periods, and surrounding tissues. ${ }^{8,12,13,19}$ Some authors suggest that dental axial inclinations be radiographically checked at the beginning and end of orthodontic treatment. $3,5,7-10,13,16,17,19$ Panoramic radiographs may be the technique of choice since it provides significant amount of diagnostic information obtained by viewing all teeth as well as the basal bone at once. In addition, it is the best option to evaluate teeth axial inclinations and root parallelism

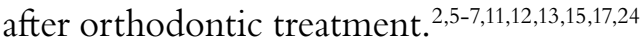

As occurring in other radiographic methods, the dimensions of structures in panoramic radiographs can be magnified ${ }^{5,7,8,11,12,13,15-19}$ and due to distortions, hori-

Table 2 - Means and standard deviations of mesiodistal inclinations of the teeth (36, 37, 46 and 47) at the three evaluation stages ( $T_{1}, T_{2}$ and $T_{3}$ ) for Groups 1 (second molars not included in treatment, $n=25$ ) and 2 (second molars included, $n=25$ ) and results of dependent ANOVA and Tukey tests.

\begin{tabular}{|c|c|c|c|c|}
\hline \multirow{2}{*}{$\begin{array}{l}\text { Molar } \\
\text { angulation }\end{array}$} & Initial $\left(T_{1}\right)$ & Posttreatment $\left(\mathrm{T}_{2}\right)$ & Postretention $\left(\mathrm{T}_{3}\right)$ & \multirow{2}{*}{$\mathbf{P}$} \\
\hline & Mean \pm SD & Mean \pm SD & Mean \pm SD & \\
\hline 36 G1 & $59.60^{\AA} \pm 5.27$ & $62.22^{A} \pm 6.57$ & $62.56^{A} \pm 5.01$ & 0.13 \\
\hline $36 \mathrm{G} 2$ & $56.80^{A} \pm 5.60$ & $66.04^{\mathrm{B}} \pm 4.87$ & $66.26^{\mathrm{B}} \pm 5.37$ & $0.00 *$ \\
\hline 37 G1 & $57.92^{A} \pm 8.07$ & $56.66^{A} \pm 6.03$ & $57.94^{A} \pm 8.35$ & 0.79 \\
\hline $37 \mathrm{G} 2$ & $55.24^{\wedge} \pm 6.70$ & $65.56^{\mathrm{B}} \pm 6.96$ & $66.50^{\mathrm{B}} \pm 6.94$ & $0.00^{*}$ \\
\hline 46 G1 & $62.92^{A} \pm 6.35$ & $67.60^{A} \pm 6.94$ & $65.08^{A} \pm 6.59$ & 0.05 \\
\hline $46 \mathrm{G} 2$ & $64.68^{A} \pm 4.08$ & $71.42^{\mathrm{B}} \pm 3.97$ & $70.88^{8} \pm 5.83$ & $0.00 *$ \\
\hline $47 \mathrm{G} 1$ & $60.54^{A} \pm 8.01$ & $62.98^{A} \pm 6.38$ & $63.52^{A} \pm 9.90$ & 0.39 \\
\hline $47 \mathrm{G} 2$ & $57.26^{A} \pm 10.24$ & $70.08^{B} \pm 8.77$ & $68.10^{B} \pm 6.03$ & $0.00 *$ \\
\hline
\end{tabular}

*Statistically significant for $p<0.05$. Different letters mean a statistically significant difference between the phases.

Table 3 - Means and standard deviations of mesiodistal inclinations of the teeth (36, 37, 46 and 47 ) at the three evaluation stages ( $T_{1}, T_{2}$ and $T_{3}$ ) for $G$ roup 2 (second molars included) and results of dependent ANOVA and Tukey tests.

\begin{tabular}{|c|c|c|c|c|}
\hline \multirow{2}{*}{$\begin{array}{c}\text { Molar } \\
\text { angulation }\end{array}$} & Initial $\left(\mathrm{T}_{1}\right)$ & Posttreatment $\left(\mathrm{T}_{2}\right)$ & Postretention $\left(\mathrm{T}_{3}\right)$ & \multirow{2}{*}{$\mathbf{p}$} \\
\hline & Mean \pm SD & Mean \pm SD & Mean \pm SD & \\
\hline 36 & $56.80^{A} \pm 5.60$ & $66.04^{\mathrm{B}} \pm 4.87$ & $66.26^{\mathrm{B}} \pm 5.37$ & $0.00 *$ \\
\hline 37 & $55.24^{A} \pm 6.70$ & $65.56^{\mathrm{B}} \pm 6.96$ & $66.50^{\mathrm{B}} \pm 6.94$ & $0.00^{*}$ \\
\hline 46 & $64.68^{A} \pm 4.08$ & $71.42^{\mathrm{B}} \pm 3.97$ & $70.88^{\mathrm{B}} \pm 5.83$ & $0.00 *$ \\
\hline 47 & $57.26^{A} \pm 10.24$ & $70.08^{\mathrm{B}} \pm 8.77$ & $68.10^{\mathrm{B}} \pm 6.03$ & $0.00 *$ \\
\hline
\end{tabular}

*Statistically significant for $p<0.05$. Different letters mean a statistically significant difference between the phases. 
zontal measurements are unreliable. ${ }^{17,19}$ In this study, panoramic radiograph magnification did not influence the results, as the same radiographic equipment and similar techniques were used for both groups. Thus, when Groups 1 and 2 were compared, the possible influence of this variable was eliminated.

Accuracy of tooth length and angulation measurements on panoramic radiographs is thought to be highly dependent on head positioning technique. ${ }^{18,20}$ Stramotas et $\mathrm{al}^{18}$ noted a significant error $(\mathrm{p}<0.05)$ in such measurements when the occlusal plane was tilted up anteriorly by 8 degrees. A lateral cant of the occlusal plane less than 10 degrees without an upward anterior rotation showed no significant effect on the measurements. Regarding angular measurements, the literature reports that the analysis of dental angulations through panoramic radiographs can be performed with good reliability $8,11,12,13,15,17,18,19$ and that there is some tolerance of variation in head position. ${ }^{18}$ During the radiographic examination, all patients who comprised the sample were positioned with both the occlusal plane parallel and the sagittal plane perpendicular to the ground.

Recent studies have compared the accuracy of assessing mesiodistal root angulations with posttreatment panoramic radiographs and with cone-beam computed tomography (CT). The results show that CT is the most accurate method for assessing dental angulation..$^{21,22}$ Thus, assessment of mesiodistal tooth angulations with panoramic radiograph should be approached with caution and reinforced by a thorough clinical examination of the dentition. ${ }^{23}$ However, due to economic as well as biological reasons, CT should not be considered for clinical routine, but rather only for mesiodistal root angulations evaluation, before, during or after orthodontic treatment. The use of panoramic radiograph as data source may be considered a limitation of this study. The use of CT could result not only in a more accurate assessment of the mesiodistal root angulations, but it could also enable tridimensional evaluation of the teeth. Another limitation of this research is the fact that it evaluated the mandibular molars changes, only.

Results of Group 1 (\#37 and \#47 teeth not included) intragroup comparison demonstrated no statistically significant differences between the mean values for the mesiodistal inclinations of the teeth $(36,37,46$ and 47$)$ at the three evaluation stages $\left(T_{1}, T_{2}\right.$ and $\left.T_{3}\right)$ (Table 2). However, results of Group 2 (37 and 47 included) intragroup comparison demonstrated significant uprighting of mandibular first and second molars during treatment, which remained stable at the postretention stage (Table 2). Regarding the assessment of changes in mesiodistal dental inclination as a result of orthodontic treatment, there are few studies that could be used for comparisons, and most of them are related to patterns of normal occlusion.

In an attempt to establish a basis for quantitative evaluation of mesiodistal axial inclinations of permanent teeth after orthodontic treatment, Ursi et a $\mathrm{l}^{13}$ conducted a study that determined the normal mean values for dental angulations through panoramic radiographs. For the authors, the mesiodistal root angulations of high quality orthodontic treatment exhibited in the final panoramic radiographs should be similar to normal occlusion values. In the present study, it was noted that the mean values obtained for the mesiodistal inclinations of the teeth (36, 37, 46 and 47) at posttreatment and postretention phases in Group 2 (with inclusion of the second molars) were closer to the normal values proposed by Ursi et al. ${ }^{13}$

In 2002, Brandão ${ }^{9}$ evaluated if alterations in the mesiodistal axial inclination of the mandibular anterior teeth would present any influence in the relapse of their crowding. The panoramic radiographic and dental casts of each patient were evaluated at the beginning $\left(\mathrm{T}_{1}\right)$, at the end $\left(\mathrm{T}_{2}\right)$ and five-year posttreatment $\left(\mathrm{T}_{3}\right)$ phases. Results showed that the mesiodistal axial inclinations of the teeth at the beginning of treatment were different from those observed in normal occlusion cases in 85\% of the evaluated teeth. However, $45 \%$ of the teeth at the end, and 55\% at the five-year posttreatment phase showed mean values similar to those of normal occlusion. Evaluation of mesiodistal axial inclination stability at the five-year posttreatment phase demonstrates that $75 \%$ of the teeth proved to maintain the angulation obtained at the end of the treatment, regardless of being similar or not to the normal values. The changes in the mesiodistal axial inclination between $\mathrm{T}_{2}$ and $\mathrm{T}_{3}$ did not influence the relapse of mandibular anterior crowding.

In 2006, Almeida-Pedrin et $\mathrm{al}^{8}$ evaluated, through panoramic radiographs, the mesiodistal axial inclinations of the maxillary anterior teeth at the beginning and end of nonextraction orthodontic treatment. The experimental sample comprised 40 Caucasian patients who were treated orthodontically with a standard Edgewise technique, without extractions. The mesiodistal axial inclinations of the maxillary anterior teeth of 
Table 4 - Intergroup comparison of mesiodistal inclinations of the teeth (36, 37, 46 and 47$)$ at the three evaluation stages ( $T_{1}, T_{2}$ and $\left.T_{3}\right)$ with $t$-test.

\begin{tabular}{|c|c|c|c|}
\hline $\begin{array}{c}\text { Molar } \\
\text { angulation }\end{array}$ & $\begin{array}{l}\text { Group } 1 \\
\text { Second molar not included } \\
\qquad(n=25)\end{array}$ & $\begin{array}{l}\text { Group } 2 \\
\text { Second molar included } \\
\qquad(n=25)\end{array}$ & $\mathbf{p}$ \\
\hline & Mean \pm SD & Mean \pm SD & \\
\hline $36 \mathrm{~T}_{1}$ & $59.60 \pm 5.27$ & $56.80 \pm 5.60$ & 0.07 \\
\hline $36 T_{2}$ & $62.22 \pm 6.57$ & $66.04 \pm 4.87$ & $0.02^{*}$ \\
\hline $36 T_{3}$ & $62.56 \pm 5.01$ & $66.26 \pm 5.37$ & $0.01^{*}$ \\
\hline $37 T_{1}$ & $57.92 \pm 8.07$ & $55.24 \pm 6.70$ & 0.20 \\
\hline $37 \mathrm{~T}_{2}$ & $56.66 \pm 6.03$ & $65.56 \pm 6.96$ & $0.00 *$ \\
\hline $37 T_{3}$ & $57.94 \pm 8.35$ & $66.50 \pm 6.94$ & $0.00 *$ \\
\hline $46 T_{1}$ & $62.92 \pm 6.35$ & $64.68 \pm 4.08$ & 0.25 \\
\hline $46 T_{2}$ & $67.60 \pm 6.94$ & $71.42 \pm 3.97$ & $0.02^{*}$ \\
\hline $46 T_{3}$ & $65.08 \pm 6.59$ & $70.88 \pm 5.83$ & $0.00 *$ \\
\hline $47 T_{1}$ & $60.54 \pm 8.01$ & $57.26 \pm 10.24$ & 0.21 \\
\hline $47 T_{2}$ & $62.98 \pm 6.38$ & $70.08 \pm 8.77$ & $0.00 *$ \\
\hline $47 T_{3}$ & $63.52 \pm 9.90$ & $68.10 \pm 6.03$ & 0.05 \\
\hline
\end{tabular}

*Statistically significant for $p<0.05$.

the experimental group at $\mathrm{T}_{1}$ were different from those of the control group for $50 \%$ of the evaluated teeth. In contrast, the inclinations at $\mathrm{T}_{2}$ were consistent with the normal anatomical configuration of the controls. The authors concluded that panoramic radiograph is an effective tool for evaluating the mesiodistal axial inclinations of maxillary anterior teeth.

In 2009 , Sella et al..$^{25}$ compared the normal mean values of mesiodistal axial angulations, proposed by Ursi et al, ${ }^{13}$ with mesiodistal axial angulations of canine teeth, premolars and inferior molars in individuals aged between 18 and 25 years old, with and without the presence of the mandibular third molars. The authors concluded that the groups presented similar angular values for the canine teeth, premolars and inferior molars in such a way that the presence of the third molars did not influence dental angulations.

The intergroup comparison (Table 4) demonstrated statistically significant differences with regards to mesiodistal inclinations of mandibular first and second molars at $\mathrm{T}_{2}$. Patients with mandibular second molars included in treatment mechanics presented mandibular first and second molars more uprighted. At $\mathrm{T}_{3}$, mesiodistal inclinations of the molars remained significantly different be- tween groups, except for the mean values for angulation of mandibular right second molars $\left(\# 47-\mathrm{T}_{3}\right)$ that, despite not statistically significant $(p=0.05)$, were, on average, approximately 5 degrees more uprighted in comparison to Group 1. There are some limitations hindering comparison between these intergroup results with other studies, namely: the nonexistence of previous studies with similar objectives in the literature and their methodological differences. However, based on the results of this research, it may be inferred that the inclusion of second mandibular molars in orthodontic mechanics benefits not only the mandibular second molars, but also first molars uprighting, as the mandibular first molars in Group 2 were more uprighted at posttreatment and postretention stages (Tables 2 and 3). Additionally, the results suggest that the inclusion of second molars in orthodontic mechanics probably consists in a distal support that improves first molar uprighting.

There are some doubts and controversies about the necessity of second molars inclusion during orthodontic treatment. Two of the major goals of treatment consist in leveling the curve of Spee and correcting overbite. Thus, nothing is more rational than using the second molars to provide an anchorage that allows anterior teeth 
intrusion and correction of the curve of Spee. When using Class II elastics, the second molar inclusion increases arch length. Therefore, there is not only an increase in the horizontal component of force, but also a decrease of the vertical component. This fact is generally favorable because it facilitates sagittal interarch adjustment and prevents first molars extrusion. In extraction cases, mandibular second molars inclusion provides posterior anchorage improvement and avoids inclination and rotation of the first molars. It is also indicated for crossbites, proclined or rotated sec- ond molars cases as well as surgical cases. However, there are clinical situations in which inclusion of second molars may be contraindicated, such as in patients with initial anterior open bite and vertical facial growth tendency.

\section{CONCLUSION}

Inclusion of mandibular second molars in orthodontic mechanics is relevant not only for the correction of mandibular second molars mesiodistal inclination, but also for first molars uprighting.

\section{REFERENCES}

1. Andrews LF. The six keys to normal occlusion. Am J Orthod. 1972;62(3):296-309.

2. Dempster WT, Adams WJ, Duddles RA. Arrangement in the jaws of the roots of the teeth. J Am Dent Assoc. 1963;67:779-97.

3. Hatasaka HH. A radiographic study of roots in extraction sites. Angle Orthod. 1976:46(1):64-8

4. Beyron H. Optimal occlusion. Dent Clin North Am. 1969:13(3):537-54

5. Ingervall B. Functionally optimal occlusion: the goal of orthodontic treatment. Am J Orthod. 1976;70(1):81-90.

6. Mayoral G. Treatment results with light wires studied by panoramic radiography. Am J Orthod. 1982;81(6):489-97.

7. Williams R. Eliminating lower retention. J Clin Orthod. 1985;19(5):342-9

8. Almeida-Pedrin RR, Pinzan A, Almeida RR, Ursi W, Almeida MR. Panoramic evaluation of mesiodistal axial inclinations of maxillary anterior teeth in orthodontically treated subjects. Am J Orthod Dentofacial Orthop. 2006:130(1):56-60.

9. Brandão AG. Estudo ortopantomográfico longitudinal das inclinações axiais mesiodistais em pacientes tratados ortodonticamente com extrações dos quatro primeiros pré-molares [dissertação]. Bauru (SP): Faculdade de Odontologia de Bauru; 2002.

10. Edwards JG. The prevention of relapse in extraction cases. Am J Orthod. 1971;60(2):128-44

11. Jesuino FA, Costa LR, Valladares-Neto J. Mesiodistal root angulation of permanent teeth in children with mixed dentition and normal occlusion. J Appl Oral Sci. 2010;18(6):625-9.

12. Lucchesi MV, Wood RE, Nortje CJ. Suitability of the panoramic radiograph for assessment of mesiodistal angulation of teeth in the buccal segments of the mandible. Am J Orthod Dentofacial Orthop. 1988;94(4):303-10

13. Ursi WJ, Almeida RR, Tavano O, Henriques JF. Assessment of mesiodistal axial inclination through panoramic radiography. J Clin Orthod. 1990;24(3):166-73.

14. Tavano O, Ursi WJS, Almeida RR, Henriques JFC. Determinação de linhas de referência para medições angulares em radiografias ortopantomográficas. Odontol Mod. 1989;16(9):22-5

15. Akcam MO, Altiok T, Ozdiler E. Panoramic radiographs: a tool for investigating skeletal pattern. Am J Orthod Dentofacial Orthop. 2003;123(2):175-81.
16. McKee IW, Glover KE, Williamson PC, Lam EW, Heo G, Major PW. The effect of vertical and horizontal head positioning in panoramic radiography on mesiodistal tooth angulations. Angle Orthod. 2001;71(6):442-51

17. McKee IW, Williamson PC, Lam EW, Heo G, Glover KE, Major PW. The accuracy of 4 panoramic units in the projection of mesiodistal tooth angulations. Am J Orthod Dentofacial Orthop. 2002:121(2):166-75.

18. Stramotas S, Geenty JP, Petocz P, Darendeliler MA. Accuracy of linear and angular measurements on panoramic radiographs taken at various positions in vitro. Eur J Orthod. 2002;24(1):43-52

19. Larheim TA, Svanaes DB. Reproducibility of rotational panoramic radiography: mandibular linear dimensions and angles. Am J Orthod Dentofacial Orthop. 1986;90(1):45-51

20. McDavid WD, Welander U, Brent Dove S, Tronjje G. Digital imaging in rotational panoramic radiography. Dentomaxillofac Radiol. 1995:24(2):68-75.

21. Bouwens DG, Cevidanes L, Ludlow JB, Phillips C. Comparison of mesiodistal root angulation with posttreatment panoramic radiographs and cone-beam computed tomography. Am J Orthod Dentofacial Orthop. 2011;139(1):126-32.

22. Van Elslande D, Heo G, Flores-Mir C, Carey J, Major PW. Accuracy of mesiodistal root angulation projected by cone-beam computed tomographic panoramic-like images. Am J Orthod Dentofacial Orthop. 2010:137(4 Suppl):S94-9

23. Owens AM, Johal A. Near-end of treatment panoramic radiograph in the assessment of mesiodistal root angulation. Angle Orthod. 2008;78(3):475-81.

24. Strang RHW. Factors associated with successful orthodontic treatment. Am J Orthod. 1952:38(10):790-800

25. Sella RC, Mendonça MR, Cuoghi OA. Avaliação ortopantomográfica das angulações mesiodistais de caninos, pré-molares e molares inferiores com e sem a presença dos terceiros molares. Rev Dental Press Ortod Ortop Facial. 2009;14(6):97-108

26. Janson M. Ortodontia em adultos e tratamento interdisciplinar. 2a ed. Maringá: Dental Press; 2010 